\title{
Islamic Veil: The Issue of Minors
}

\section{Renata Tokrri}

$\mathrm{PhD}$, Lecturer at the University "Aleksandër Moisiu" Durrës-Albania

\section{Abstract}

An important aspect of the Albanian public debate on the exposure of religious symbols concerned minors. In fact, the proposed government law of 2011 was addressed to a category of public school education, that is, regarding students from kindergarten to secondary school. The Islamic veil was always at the center of the debate, but in this case the prohibition was justified as it was aimed at an age group that did not have the ability to make decisions and make choices independently, as in Muslim religion it is expected that a postpubertal girl must wear a headscarf. In fact, in this case the decision-making passes to the parents, who have the right to educate their children according to the dictates of his own conscience. It is stressed that the same circumstance also applies to other religions, where the decision is always made by parents, such as baptism in the Catholic religion. In particular, the Article 24 of the Albanian Constitution, explicitly sanctions the freedom of each person to choose their belief and the prohibition that no one should be forced to participate in the life of a religious community or its practices. The question that arises in this case is whether this constitutional article also protects this category of subjects or only those who have reached the age of majority? The answer is complex and delicate, even to date the Albanian legislator has not remedied it since no one has appealed.

Keyword: Albanian constitution, freedom of religion, religious symbols, Islamic headscarf, the right to educate your own children.

\section{Introduction}

The origin of the veil is lost in the mists of time, a symbol of spirituality, mystery and purity, but also of wealth because in ancient times it was worn by high-ranking women. So also the Muslim religion, not different from the others, has promoted social equality, therefore the veil becomes an economic and imitation symbol.

The veil hides the woman from prying eyes to reveal her only to God and master. In this regard we read in the Koran,

"And say to the believing women (that) they should lower [of] their gaze and they should guard their chastity, and not (to) display their adornment except what is 
apparent of it. And let them their head covers over their bosoms, and not (to) display their adornment except to their husbands, or their fathers or fathers (of) their husbands or their sons or sons (of) their husbands or their brothers or sons (of) their brothers or sons (of) their sisters, or their women..." (Koran, XXIV, 31), and then, " $O$ Prophet, tell your wives and your daughters and the women of the believers to bring down over themselves [part] of their outer garments.....". (Koran, XXXIII, 59).

Without a doubt these verses leave ample space to free interpretation, this is the reason why the Islamic veil also takes multiple forms, as different as the interpretations are, for example hijab, niqab, chador, burqa.

It is important to emphasize that the veil is not a uniquely symbol of the Muslim religion, but we find it in the Jewish, Catholic and Orthodox religion, for example in nuns, the virgin Mary is always represented veiled. But despite this, the female headscarf is often perceived and identified as a symbol exclusively of the Muslim religion. This perhaps derives from a numerical fact, as it is the obligation of every Muslim woman to wear it, even if it appears that the Koran does not provide for any sanction for women who do not wear it.

The obligation to veil "the beautiful parts" begins in a post-pubic age when one is almost inconscious of the relationship with the Divine, that is, when the girls attend the school.

But often, externalization in European societies when a certain Islamophobia is often found, the veil worn by a minor can lead to an insane integration and an insane psychic development, as it can feel excluded from school social life and as a consequence from right to have equal development. The problem is based on the fact that the minor cannot oppose a history of imposition, unlike a woman of an older age, where the veil can be a personal choice. Here, the veil from a symbol of purity becomes a symbol that separates and isolates, even more if it is worn in a non-voluntary way.

Different cultures conceive the family and education differently, but what unites all families is to desire the happiness of their children. The family is the place where the minor is educated to be prepared for the flight of life, but at the same time deeply attached to their roots. For this reason the family becomes the lighthouse in an open sea, leaving the child free to navigate and explore his own spirituality, for this reason the family should not be "closed" but "open", that is, able to understand the psychological and social needs of their children.

Equally like the family, society too must be "open", an open and peaceful European society that transmits acceptance values as fundamental principles. As in a "closed" family, in a "closed" multicultural European society, the veil is a polysemic symbol and can have different meanings, here the veil as a symbol of spirituality can become a symbol of submission, backwardness, alienation, isolation and of civilization, and without a doubt it becomes a symbol of multiculturalism incapable of coexistence. 
The veiled woman proposes herself as a new feminine model, in contrast to the "unveiled" woman. A veleta woman symbol of a rediscovered feminine dignity or symbol of submisine? But it will not be here or in any other to analyze which is the best feminine model as the only intention of the writer is to identify the legal condition and constitutional protection, with the ambition to identify the rights and freedom because no woman can be subordinated or physically and psychologically forced to conceal her identity.

But even more delicate and complex is the situation when there is a minority behind a veil.

\section{The Islamic veil and the legal status of the minor in Albania}

The 2011 government bill was aimed at a category of public school education, that is, concerning students from kindergarten to secondary school. The Islamic veil was always at the center of the debate, but in this case the prohibition was justified as it was aimed at an age group that did not have the ability to make decisions and make choices independently, as in Muslim religion it is expected that a post-pubertal girl must wear a headscarf. In fact, in this case the decision-making process passes to the parents, who have the right to educate their children according to the dictates of their conscience. It is emphasized that the same circumstance also applies to other religions, where the decision is always made by parents, such as baptism in the Catholic religion.

The new Albanian Constitution of 1998 could not renounce the postulate of freedom of religion, since its omission during the communist regime has led to a real religious genocide for the country. For this reason, the new Constitution contains a kind of favore religionis, this originates from not only historical but also current circumstances, which see the former country that had declared war on God to commit itself to safeguarding the peace of a multi-religious society.

In this regard, it should be noted that art. 24 of the Constitution explicitly establishes that every person is free to choose his or her own creed, furthermore it states that no one should be "forced to participate in the life of a religious community or its practices, as well as to make public their beliefs or faith". In light of this article, the questions that arise are manifold, if art. 24 of the Albanian Constitution also protects minors or only those who have come of age? And, if this rule can be a limit to the right of parents to educate their children? The answers are complex and delicate, even to date the Albanian legislator has not remedied since no one has appealed.

Who's writing believes that it is not questionable that the Constitutional rules that concern fundamental rights and freedoms and that do not provide for age limits - such as for example the right to vote - also hold the subjects of minor age. Moreover, these subjects are active in the enjoyment of fundamental rights. 
If on the one hand, the right of parents to educate their children in the religion they want cannot be denied, on the other hand, the inclination and freedom of children to be able to believe freely and without constraints is a requirement that must be respected. (A. C. JEMOLO, 1962; F. FINOCCHIARO, 2003; R. BOTTA, 1998).

In this regard, no provision is found in the Albanian Constitution that makes parents responsible for the religious education of their children, such as in the Polish Constitution of 1997 (art. 53) or the Romanian Constitution of 1991 (art. 29).

This question takes us back to the communist period where in the Constitution of the Socialist People's Republic of 1976, it was sanctioned in art. 33 that education was based on the secular tradition of the nation but built "On the Marxist-Leninist conception of the world", and according to the third paragraph of art. 49, the parents were responsible for "the communist education of children". (M. L. Lo GIACCO, 2003). Unlike the Constitution of the old regime, the new Constitution makes no mention of this, leaving a gap in the matter.

\section{International protection of minors}

The New York Convention on the Rights of the Child of 1989 is one of the first international charters that guarantee fundamental freedoms, without doubt also including freedom of religion, conscience, etc.

"The Cairo Declaration on Human Rights in Islam" of 1990, in which parental rights are subordinated to the interests of their children, can also help. In particular in art. 7 reads that "Parents and those in similar conditions have the right to choose the type of education they want for their children, provided that they take into consideration the interest and future of the children in accordance with the ethical values and principles of Shari'ah " (A. PACINI (by), 1998; G. DAMMACCO, 2000).

In this way, the full development of the minor's personality is protected, taking into consideration of his natural inclination, this in respect of the freedom of conscience and human dignity which even those who have not reached the age of majority are entitled to. Thus, we can argue that children, even if minors, have a certain autonomy in the self-determination of the choices that involve the religious sphere. (A. TESTORI CICALA, 1988).

In the case of minors, the interpretation cannot be absolute. But this issue must be taken into consideration on a case-by-case basis by the legislator and the judges, because it is a problem that can take on different nuances, for example in the case where parents for religious reasons can refuse health treatments necessary for their children, from which prejudice to health may arise, or in the case of parents divorced with different faith, etc. At the moment, no similar cases have been presented to the Albanian judge and we do not know what his position might be. Of course, education must be consistent with one's religious faith or belief, respecting the interest and personality of the minor and without doubts without creating harm to health. So the 
freedom to educate your children meets the limit of the principle of selfdetermination of the same.

We can therefore say that as regards the obligation to wear the Islamic veil as children, the matter should be resolved by balancing the right - duty of parents to educate their children and their interest, where the latter must undoubtedly prevail. (Position also taken by the French Court, judgment no. 1606 of October 24, 2000).

As you can see, the topic has very delicate elements and balancing interests is very difficult. (M. L. LO GIACCO, 2007).

\section{Islamic veil and the secular principle of the state}

The issue of the Islamic veil worn by minors, and the Italian case of the exposure of religious symbols in public schools and the veil or chador worn by a teacher, are revealed to be sides of the same coin, as in all three cases the parents ask in the interest of the offspring to be the one to choose religious education, without external conditions. The only difference between the three situations is that, on the one hand, religious indoctrination derives from the state, which by constitution must be secular,the other from the parent who has the duty to educate the children with respect for their dignity, and finally by a teacher who has the right to express her belief and to follow the canonical obligations, because wearing the Islamic veil is not only one exposure. (N. FIORITA, 2006; A. PIN, 2006).

These relationships, (family, school, minor) are intertwined in order to make it increasingly difficult to identify the limits of one and the other. Without a doubt that the school-family relationship must be a relationship of trust-respect, because in these two institutions the personality of the child develops. Besides, religion plays a very important role in the spiritual growth of the child. All three of these institutions must try to coexist peacefully for the supreme good, that is, the good of the minor.

The secular and neutral state must respect the right of parents to educate their children, but must ensure that education in pluralism must begin in a neutral environment with respect for the religious freedom of all students or teachers.

In fact, this delicate balance can be the key to peaceful coexistence, where the secular state is the guarantor of freedoms, because in a perspective in which it limits individuals to freely manifest their religiosity, it takes the form of an anti-religious or atheist state and secularism is not synonymous with anti-religiousity, but respect for all beliefs. In a secular context, the social pact is founded between autonomous, free and equal individuals, (S. TARANTO, 2013) in a perspective where "individuals must consider themselves free to express their cultural and religious identity also through the use of signs of belonging - with the limit of those forms of clothing that cover the face, preventing the recognition of the person and hindering relationships social -, it remains excluded that the sacred symbols and images of a religious confession can be 
authoritatively displayed in the institutional public sphere, as if the State could identify with them". (G. BRUNELLI, 2007).

Because, recognizing the freedom of religion means "respecting the spiritual autonomy of man, of every man", for this reason "it would be contradictory, in claiming one's freedom, to cut it off to another, or even to mortify it in its dignity" (G. LO CASTRO, 1996). In this perspective, secularism means "recognizing the legitimacy of the expression of the thoughts of others, without abuse, without dogmatic pretensions" (M. MARCONI).

For this it must be underlined that, the European dream must not inflict on the Albanians a nihilistic spirit, in the sense that the country must not deny itself, and the aim of its pluralist democracy must be to promote peaceful coexistence and the "good life". (R. DWORKIN, 2002,).

In the wake of these considerations, a concept of secularism derives as neutrality, which affects not only the public sphere but also the individual's private sphere, guaranteeing the expression of his personality also in public life. So this seems to be the compass to follow in cases like these, because, as Rawls also argues, freedom has priority (J. RAWLS, 1971), and "the authority and the state no longer appear to be the holders of absolute truth and ethics: thus the idea of a public political space, purified from metaphysical visions of human existence, appears on the scene. State institutions and government must be impartial and neutral; collective choices must have a rational justification, public and independent of the world's religious perspectives. Politics, law and religion thus become distinctly concepts, although strictly interdependent". (S. TARANTO, 2013).

The deeper core of the principle of secularism implies "promotion of openness, tolerance and freedom of action in the various spheres of public life" (M. D'AMICO, A. PUCCIO, 2009), therefore it is the task of the State and of the modern Constitutions, as Rawls points out, to guarantee the full autonomy man.

\section{Conclusions}

Today Europe is a theater where multiculturalism stages different cultures, customs, rites and religions, often counterposed and often unacceptable.The thin red line always seems close, and it is difficult to accept the different. For a minor, this reality is even more palpable, when it is divided between two worlds, between two cultures, between two realities. The question that arises is, when should the state intervene to protect the minor, when should the institutions interpret a certain custom as a red line?

It is clear that the right to exercise juvenile infibulation or physical or mental constraint to follow a particular cult cannot be expected to be recognized in Europe (as indeed nowhere should happen). It goes without saying that the judge of merit or of law, when called upon to pronounce on a question concerning the legitimate 
freedom of worship, including whether or not the institutions should display religious symbols, must strictly adhere to the principle of secularism and correct neutrality of the State and the principle of self-determination of the minor of the choices that involve the religious sphere.

As for Albania, as we highlighted in the previous pages, the new Constitution of 1998 expresses principles that protect the religious phenomenon since its preamble. So the art. 24 of the Constitution, protects the freedom of religion and conscience in a perspective where everyone is free to choose or change their beliefs or beliefs, to manifest them individually or collectively both in public and in private life through worship, teaching, practices and observance of rites. Likewise, this article provides that no one should be hindered or forced to participate in the life of a religious community or its practices, as well as to make public their beliefs or faiths. Without any doubt, these rules also apply to people of minor age.

Also the same judge found in front of a minor, must take into account that the so-called technique of balancing constitutional rights in this case is unacceptable, since between the right of the parent to educate and give the child a religious education, and the right of the minor to self-determination so that he freely forms his own conscience, the right always prevails of the minor. Undoubtedly in social reality this question is more an iron-cinder between child and parent, where the strongest would win who does not always correspond to the most just, but in legal reality the minor is the supreme good.

But, in the event that wearing the veil is the result of an autonomous spiritual path of the minor and a personal choice, then, Article 24 of the Constitution comes to our aid which guarantees this choice.

In Albania, but also in other European countries, the institutions must accept this choice even if the fleece is not a collective symbol, but even these companies are not unitary in culture, but fragmented, and this must not preclude the right to keep an individual symbol.

\section{References}

[1] Aa.Vv., La Laicità Crocifissa? Il Nodo Costituzionale Dei Simboli Religiosi Nei Luoghi Pubblici, (by) R. Bin, G. Brunelli, a. Pugiotto, P. Veronesi, Giappichelli, Turin, 2004.

[2] Botta R., Manuale Di Diritto Ecclesiastico. Valori Religiosi E Società Civile, Ii Ed., Turin, Giappichelli, 1998.

[3] Brunelli G., Simboli Collettivi E Segni Individuali Dell'appartenenza Religiosa, Le Regole Della Neutralità, in Annuario 2007.

[4] D’amico M., Puccio a., Laicità Per Tutti, Franco Angeli, Milan, 2009.

[5] Dammacco G., Diritti Umani E Fattore Religioso Nel Sistema Multiculturale Euromediterraneo, Bari, Cacucci, 2000. 
[6] Dworkin R., Virtù Sovrana. Teoria Dell'eguaglianza (2000), Ita. Trans., Milan, Feltrinelli, 2002.

[7] Finocchiaro F., Diritto Ecclesiastico, Ix Ed., Bologna, Zanichelli, 2003.

[8] Fiorita N., La Resistibile Ascesa Di Un Simbolo Religioso: Storia Recente Del Crocefisso, in Quaderni Di Diritto E Politica Ecclesiastica, 2006.

[9] Jemolo C., Lezioni Di Diritto Ecclesiastico, Iii Ed., Milan, Giuffrè, 1962.

[10] Lo Castro G., La Libertà Religiosa E L'idea Di Diritto, in Dir. Eccl., 1996, I.

[11] Lo Giacco M. L., Diritto All'istruzione, Pluralismo Scolastico E Libertà Religiosa in Italia E in Albania, in Il Diritto Ecclesiastico, 2003, I.

[12] Lo Giacco M. L., Educazione Religiosa E Tutela Del Minore Nella Famiglia, in Stato, Chiese E Pluralismo Confessionale, Rivista Telematica - February 2007.

[13] Marconi M., Laicità E Laicismo: Una Falsa Dicotomia, in Www.Uaar.It.

[14] Pacini a., (by), L'islam E Il Dibattito Sui Diritti Dell'uomo, Turin, Edizioni Della Fondazione Giovanni Agnelli, 1998.

[15] Pin a., Il Percorso Della Laicità "All'italiana". Dalla Prima Giurisprudenza Costituzionale Al Tar Veneto: Una Sintesi Ricostruttiva, in Quaderni Di Diritto E Politica Ecclesiastica, 2006.

[16] Rawls J., Una Teoria Della Giustizia, 1971, Feltrinelli, Milan, 2008.

[17] Taranto S., Diritti E Libertà Al Tempo Della Secolarizzazione, Della Tolleranza Religiosa, Della Laicità Un'analisi Concettuale, in Ragion Pratica, 40/ June 2013.

[18] Taranto S., Diritti E Libertà Al Tempo Della Secolarizzazione, Della Tolleranza Religiosa, Della Laicità Un'analisi Concettuale, in Ragion Pratica, 40/ June 2013.

[19] Testori Cicala a., L'autodeterminazione Dei Minori Nelle Opzioni Religiose E Sociali, in Il Diritto Di Famiglia E Delle Persone, 1988. 